\title{
Energy Analysis of Irrigated Jetropha Cultivation for Producing Biodiesel
}

\author{
Akshay Gupta, Kv Bharadwaj, Suvha Lama, Jyotirmay Mathur
}

Malaviya National Institute of Technology, Jaipur, India.

Email: jyotirmay.mathur@gmail.com

Received June $23^{\text {rd }}, 2010$; revised October $10^{\text {th }}, 2010$; accepted November $4^{\text {th }}, 2010$.

\begin{abstract}
Increase in yield of Jetropha plantation due to irrigation has been investigated considering the energy required to pump out underground water for Jetropha plantation in India. Depth of the water table is the variable. Comparison has been made with unirrigated Jetropha cultivation and increase in yield of bio-diesel has been compared with the primary energy required for operating the water pumps. Analysis has been carried out for areas having low, medium and high rainfalls and with three depths of water tables $20 \mathrm{~m}, 40 \mathrm{~m}$ and $60 \mathrm{~m}$. It has been found that in areas having low rainfall and depth of water table $40 \mathrm{~m}$, the energy balance is negative for first 4 years. Whereas in areas having low rainfall but water table $20 \mathrm{~m}$, energy balance becomes positive in the third year, whereas for $60 \mathrm{~m}$ depth, it doesn't become positive in the fifth year even.
\end{abstract}

Keywords: Energy Analysis, Energy Balance, Pump Power, Primary Energy Equivalent, Energy Yield Stabilization Matrix

\section{Introduction}

Biodiesel refers to a vegetable oil or animal fat based diesel fuel consisting of a long chain alkyl esters. The major components of vegetable oils and animal fats are tri-acyl-glycerols (TAG). Chemically, TAG's are esters of fatty acids (FA) with glycerol. Biodiesel can be produced from a great variety of feedstocks. These feedstocks include most common vegetable oils (e.g., soybean, cottonseed, palm, peanut, rapeseed/canola, sunflower, safflower, coconut) and animal fats (usually tallow) as well as waste oils (e.g., used frying oils). The choice of feedstock depends largely on geography.

Biodiesel has several distinct advantages compared with petro-diesel in addition to being fully competitive with petro-diesel in most technical aspects:

- Derivation from a renewable domestic resource, thus reducing dependence on and preserving petroleum

- Biodegradability

- Reduction of exhaust emissions (with the exception of nitrogen oxides, $\mathrm{NO}_{\mathrm{X}}$ ).

- Higher flash point, leading to safer handling and storage.

- Excellent lubrication of the engine, a fact that is steadily gaining importance with the advent of low-sulfur petro diesel fuels, which have greatly reduced lubricity. Adding biodiesel at low levels (1-2\%) restores the lubricity.

Biofuel development in India centers mainly around the cultivation and processing of Jatropha plant seeds which are very rich in oil $(40 \%)$. Jatropha oil has been used in India for several decades as biodiesel to cater to the diesel fuel requirements of remote rural and forest communities; Jatropha oil can be used directly after extraction (i.e. without refining) in diesel generators and engines. Jatropha provides immediate economic benefits at the local level since it grows well in dry marginal non-agricultural lands, thereby allowing villagers and farmers to leverage non-farm land for income generation. As well, increased Jatropha oil production delivers economic benefits to India on the macroeconomic or national level as it reduces the nation's fossil fuel import bill for diesel production (the main transportation fuel used in the country); minimizing the expenditure of India's foreign-currency reserves for fuel allowing India to increase its growing foreign currency reserves (which can be better spent on capital expenditures for industrial inputs and production). And since Jatropha oil is carbon-neutral, large-scale production will improve the 
country's carbon emissions profile. Finally, since no food producing farmland is required for producing this biofuel (unlike corn or sugar cane ethanol, or palm oil diesel), it is considered the most politically and morally acceptable choice among India's current biofuel options; it has no known negative impact on the production of the massive amounts grains and other vital agriculture goods India produces to meet the food requirements of its massive population. Other biofuels which displace food crops from viable agricultural land such as corn ethanol or palm biodiesel have caused serious price increases for basic food grains and edible oils in other countries. Jatropha plant cultivation and subsequent production of bio-fuel is a crucial part of India's plan to attain energy sustainability.

The paper on 'Jatropha biodiesel production and use' by Achten [1] discusses the best available methods, their shortcomings and the potential risks and remedies for each production step. Work done by Mr. Mukherjee, Department of Horticulture, Agricultural Research Center, Jaipur provides insights into cultivation practices and economic feasibility of Jatropha plantation, its use as an alternative fuel and as a tool for protection of environment. The information regarding pump energy and related data was obtained from 'Pump Life Cycle Costs: A Guide to LCC Analysis for Pumping Systems', an executive summary developed in collaboration between Hydraulic Institute, Europump and the US Department of Energy's Office of Industrial Technologies. Data generated in these and various other research papers was applied in our research work in estimation of the feasibility of Jatropha plantation with regard to the amount of rainfall and the depth of the water table of a particular area. Scope of this work covered finding the energy balance of irrigated Jetropha cultivation of obtaining biodiesel by calculating the primary energy consumption for water pumping from underground water sources and comparing the same with the calorific value of the bio-diesel.

\section{Primary Energy Requirement for Irrigation}

In many parts of rural India, the major source of irrigation is wells. So we used the energy required for the pumps to pull water from the wells as our input energy. The water table depth is very low in few states, such as Rajasthan. The depth of the ground water table varies from few meters to almost $100 \mathrm{~m}$ in some areas, meaning we need to dig almost $300 \mathrm{ft}$ to reach the water table. In some parts, the depth of the water table is decreasing rapidly at approximately 2-3 $\mathrm{m}$ each year [2].

The first step in calculating the energy required for water pump, the following correlation for pump power was used [3]

$$
P=(Q * H) /\left(366 * \eta_{p} * \eta_{m}\right)
$$

where,

$Q$ - Volumetric flow rate, $H$ - Depth of the water, $\eta_{p} \eta_{m}-$ Efficiencies of pump and motor respectively

The required water quantity ' $Q$ ' was calculated using the fact that the irrigational requirement of Jetropha Karkus plant species is $1500 \mathrm{~mm}$ water per hectare per year [4]. Assuming one hectare of plantation, the irrigational requirement was converted as:

$$
Q=1.5 * 10000 \mathrm{~m}^{3} / y r
$$

$10 \mathrm{hrs}$ per day is considered as the duration of watering of the plant [4]. Hence the volumetric flow rate is:

$$
Q=41.1 \mathrm{~m}^{3} / y r
$$

The average efficiency of the pump and motor combined $\left(\eta_{p} * \eta_{m}\right)$ is considered to be approx. 63.5\% [5]

$$
\eta_{p} * \eta_{m}=0.635
$$

After substitution of these values, the only remaining variable in (1) is the depth of the water table. Assuming the water table depth from ground level to be ' $H$ ' meters, we calculate the energy required to pump the water

$$
\begin{aligned}
E_{\text {input }, \text { electrical }} & =(1500 * H) /(366 * 0.635) K W h_{e l} \\
& =64.54 *(H) K W h_{e l}
\end{aligned}
$$

Considering the primary energy to electrical energy average conversion factor to be $30 \%$ [6], primary energy equivalent of electrical energy used for water pumping can be calculated as given below:

$$
\begin{aligned}
E_{\text {inputprimary }} & =64.54 * 3600 *(H) / 0.33 \\
& =697.101 *(H) M J_{\text {primary }} \text { energy } / \text { ha } / y r
\end{aligned}
$$

\section{Calculation of Energy Output as Biodiesel}

Information about increase in yield of Jetropha kurkas with irrigation was collected from the Agricultural Research Institute of India (ARII), Jaipur [7]. There is a marked difference between the net yield from a rain fed plants and irrigated plants as shown in Tables 1, 2 and 3. This difference increased considerably with increase in number of years, varying from $250 \mathrm{~kg}$ seeds/hectare of yield in the first year to almost $8000 \mathrm{~kg}$ seeds/hectare of yield by the $6^{\text {th }}$ year onwards. This data was concentrated to the arid regions of Rajasthan and taking the average rainfall of about $600 \mathrm{~mm}$ per year into consideration [2].

Since after the end of fifth year, the yield in both the categories does not change, the energy balance calculations have been carried out only for first five years. If the energy balance is negative at the end of fifth year, the deficit of energy would never reduce thereafter. 
Let us assume that increase in yield is $\mathrm{X} \mathrm{kg} \mathrm{seeds/}$ hectare of plantation. Considering 38\% oil in the seed cake, $90 \%$ efficiency of mechanical extraction, Calorific value of the oil obtained as $40 \mathrm{MJ} /$ litre and specific gravity of the oil as $0.913 \mathrm{~g} / \mathrm{cm}^{3}$ [5], the total energy obtained from the plant is calculated as:

$$
\begin{aligned}
E_{\text {outputprimary }} & =\left(X * 0.38 * 0.9 * 40 * 10^{3} / 0.913\right) \\
& =14.983 *(X) M J \text { of energy } / \text { ha } / y r
\end{aligned}
$$

Table 1. Yield of jetropha due to irrigation.

\begin{tabular}{cccc}
\hline $\begin{array}{c}\text { Year after } \\
\text { planting }\end{array}$ & $\begin{array}{c}\text { Expected } \\
\text { yield-Rain fed } \\
\text { (kg seeds/ha/yr) }\end{array}$ & $\begin{array}{c}\text { Expected } \\
\text { yield-Irrigated } \\
\text { (kg seeds/ha/yr) }\end{array}$ & $\begin{array}{c}\text { Change in yield } \\
\text { (kg seeds/ha/yr) }\end{array}$ \\
\hline $\mathbf{1}^{\text {st }}$ & - & 250 & 250 \\
$\mathbf{2}^{\text {nd }}$ & 250 & 1000 & 750 \\
$\mathbf{3}^{\text {rd }}$ & 1000 & 2500 & 1500 \\
$\mathbf{4}^{\text {th }}$ & 2000 & 5000 & 3000 \\
$\mathbf{5}^{\text {th }}$ & 3000 & 8000 & 5000 \\
$\mathbf{6}^{\text {th }}$ and \\
onwards
\end{tabular}

Table 2. Total yield of jetropha without irrigation (MT seeds/ha).

\begin{tabular}{cccc}
\hline & Low & Normal & High \\
\hline Year 1 & 0.10 & 0.25 & 0.40 \\
Year 2 & 0.50 & 1.00 & 1.50 \\
Year 3 & 0.75 & 1.25 & 1.75 \\
Year 4 & 0.90 & 1.75 & 2.25 \\
Year 5 & 1.10 & 2.00 & 2.75 \\
\hline
\end{tabular}

Table 3. Total yield of jetropha with irrigation (MT seeds/ ha).

\begin{tabular}{cccc}
\hline & Low & Normal & High \\
\hline Year 1 & 0.75 & 1.25 & 2.50 \\
Year 2 & 1.00 & 1.50 & 3.00 \\
Year 3 & 4.25 & 5.00 & 5.00 \\
Year 4 & 5.25 & 6.25 & 8.00 \\
Year 5 & 5.25 & 8.00 & 12.50 \\
\hline
\end{tabular}

\begin{tabular}{|c|c|c|c|c|c|c|c|}
\hline Year & $\begin{array}{l}\text { Yield Without } \\
\text { Irrigation } \\
\text { (MT seeds/ha/yr) }\end{array}$ & $\begin{array}{c}\text { Yield with } \\
\text { irrigation } \\
\text { (MT seeds/ha/yr) }\end{array}$ & $\begin{array}{l}\text { Increase in Yield } \\
\text { (MT seeds/ha/yr) }\end{array}$ & $\begin{array}{l}\text { Energy Output } \\
\text { due to increase in } \\
\text { Yield (kJ) }\end{array}$ & $\begin{array}{l}\text { Energy required } \\
\text { for irrigation } \\
(\mathbf{k J})\end{array}$ & $\begin{array}{l}\text { Energy Balance } \\
\text { (Out-In) (kJ) }\end{array}$ & $\begin{array}{c}\text { Cumulative } \\
\text { Energy Balance } \\
\text { (kJ) }\end{array}$ \\
\hline \multicolumn{8}{|c|}{ Low rainfall and $20 \mathrm{~m}$ depth } \\
\hline 1 & 0.1 & 0.75 & 0.65 & 9737 & 13942 & -4205 & -4205 \\
\hline 2 & 0.5 & 1.0 & 0.5 & 7490 & 13942 & -6452 & -10657 \\
\hline 3 & 0.75 & 4.25 & 3.5 & 52430 & 13942 & 38488 & 27831 \\
\hline 4 & 0.9 & 5.25 & 4.35 & 65163 & 13942 & 51221 & 79052 \\
\hline 5 & 1.1 & 5.25 & 4.11 & 61567 & 13942 & 47625 & 126677 \\
\hline \multicolumn{8}{|c|}{ Normal Rainfall and $20 \mathrm{~m}$ Depth } \\
\hline 1 & 0.25 & 1.25 & 1.0 & 14980 & 13942 & 1038 & 1038 \\
\hline 2 & 1.0 & 1.5 & 0.5 & 7490 & 13942 & -6452 & -5414 \\
\hline 3 & 1.25 & 5.0 & 3.75 & 56175 & 13942 & 42233 & 36819 \\
\hline 4 & 1.75 & 6.25 & 4.5 & 67410 & 13942 & 53468 & 90287 \\
\hline 5 & 2.0 & 8.0 & 6.0 & 89880 & 13942 & 75938 & 166225 \\
\hline \multicolumn{8}{|c|}{ High Rainfall and $20 \mathrm{~m}$ Depth } \\
\hline 1 & 0.4 & 2.5 & 2.1 & 31458 & 13942 & 17516 & 17516 \\
\hline 2 & 1.5 & 3.0 & 1.5 & 22470 & 13942 & 8528 & 26044 \\
\hline 3 & 1.75 & 5.0 & 3.25 & 48685 & 13942 & 34743 & 60787 \\
\hline 4 & 2.25 & 8.0 & 5.75 & 86135 & 13942 & 72193 & 132980 \\
\hline 5 & 2.75 & 12.5 & 9.75 & 146055 & 13942 & 132113 & 265093 \\
\hline
\end{tabular}

Table 4. Energy balance for jetropha plantation with $20 \mathrm{~m}$ water table depth. 
Table 5. Energy balance for jetropha plantation with $40 \mathrm{~m}$ water table depth.

\begin{tabular}{|c|c|c|c|c|c|c|c|}
\hline Year & $\begin{array}{l}\text { Yield Without } \\
\text { Irrigation } \\
\text { (MT seeds/ha/yr) }\end{array}$ & $\begin{array}{c}\text { Yield with } \\
\text { irrigation } \\
\text { (MT seeds/ha/yr) }\end{array}$ & $\begin{array}{l}\text { Increase in Yield } \\
\text { (MT seeds/ha/yr) }\end{array}$ & $\begin{array}{c}\text { Energy Output } \\
\text { due to increase in } \\
\text { Yield (kJ) }\end{array}$ & $\begin{array}{c}\text { Energy required } \\
\text { for irrigation } \\
(\mathbf{k J})\end{array}$ & $\begin{array}{l}\text { Energy Balance } \\
\text { (Out-In) (kJ) }\end{array}$ & $\begin{array}{c}\text { Cumulative } \\
\text { Energy Balance } \\
(\mathbf{k J})\end{array}$ \\
\hline \multicolumn{8}{|c|}{ Low Rainfall and $40 \mathrm{~m}$ Depth } \\
\hline 1 & 0.1 & 0.75 & 0.65 & 9737 & 27884 & -18147 & -18147 \\
\hline 2 & 0.5 & 1.0 & 0.5 & 7490 & 27884 & -20394 & -38541 \\
\hline 3 & 0.75 & 4.25 & 3.5 & 52430 & 27884 & 24546 & -13995 \\
\hline 4 & 0.9 & 5.25 & 4.35 & 65163 & 27884 & 37279 & 23284 \\
\hline 5 & 1.1 & 5.25 & 4.11 & 61567 & 27884 & 33683 & 56967 \\
\hline \multicolumn{8}{|c|}{ Normal Rainfall and $40 \mathrm{~m}$ Depth } \\
\hline 1 & 0.25 & 1.25 & 1.0 & 14980 & 27884 & -12904 & -12904 \\
\hline 2 & 1.0 & 1.5 & 0.5 & 7490 & 27884 & -20394 & -33298 \\
\hline 3 & 1.25 & 5.0 & 3.75 & 56175 & 27884 & 28291 & -5007 \\
\hline 4 & 1.75 & 6.25 & 4.5 & 67410 & 27884 & 39526 & 34519 \\
\hline 5 & 2.0 & 8.0 & 6.0 & 89880 & 27884 & 61996 & 96515 \\
\hline \multicolumn{8}{|c|}{ High Rainfall and $40 \mathrm{~m}$ Depth } \\
\hline 1 & 0.4 & 2.5 & 2.1 & 31458 & 27884 & 3574 & 3574 \\
\hline 2 & 1.5 & 3.0 & 1.5 & 22470 & 27884 & -5414 & -1840 \\
\hline 3 & 1.75 & 5.0 & 3.25 & 48685 & 27884 & 20801 & 18961 \\
\hline 4 & 2.25 & 8.0 & 5.75 & 86135 & 27884 & 58251 & 77212 \\
\hline 5 & 2.75 & 12.5 & 9.75 & 146055 & 27884 & 118171 & 195383 \\
\hline
\end{tabular}

Table 6. Energy balance for jetropha plantation with $60 \mathrm{~m}$ water table depth.

\begin{tabular}{|c|c|c|c|c|c|c|c|}
\hline Year & $\begin{array}{c}\text { Yield Without } \\
\text { Irrigation } \\
\text { (MT seeds/ha/yr) }\end{array}$ & $\begin{array}{c}\text { Yield with } \\
\text { irrigation } \\
\text { (MT seeds/ha/yr) }\end{array}$ & $\begin{array}{l}\text { Increase in Yield } \\
\text { (MT seeds/ha/yr) }\end{array}$ & $\begin{array}{l}\text { Energy Output } \\
\text { due to increase in } \\
\text { Yield (kJ) }\end{array}$ & $\begin{array}{c}\text { Energy required } \\
\text { for irrigation } \\
(\mathbf{k J})\end{array}$ & $\begin{array}{c}\text { Energy Balance } \\
\text { (Out-In) (kJ) }\end{array}$ & $\begin{array}{c}\text { Cumulative } \\
\text { Energy Balance } \\
(\mathbf{k J})\end{array}$ \\
\hline \multicolumn{8}{|c|}{ Low Rainfall and $60 \mathrm{~m}$ Depth } \\
\hline 1 & 0.1 & 0.75 & 0.65 & 9737 & 41826 & -32089 & -32089 \\
\hline 2 & 0.5 & 1.0 & 0.5 & 7490 & 41826 & -34336 & -66425 \\
\hline 3 & 0.75 & 4.25 & 3.5 & 52430 & 41826 & 10604 & -55821 \\
\hline 4 & 0.9 & 5.25 & 4.35 & 65163 & 41826 & 23337 & -32484 \\
\hline 5 & 1.1 & 5.25 & 4.11 & 61567 & 41826 & 19741 & -12743 \\
\hline \multicolumn{8}{|c|}{ Normal Rainfall and $60 \mathrm{~m}$ Depth } \\
\hline 1 & 0.25 & 1.25 & 1.0 & 14980 & 41826 & -26846 & -26846 \\
\hline 2 & 1.0 & 1.5 & 0.5 & 7490 & 41826 & -34336 & -61182 \\
\hline 3 & 1.25 & 5.0 & 3.75 & 56175 & 41826 & 14349 & -46833 \\
\hline 4 & 1.75 & 6.25 & 4.5 & 67410 & 41826 & 25584 & -21249 \\
\hline 5 & 2.0 & 8.0 & 6.0 & 89880 & 41826 & 48054 & 26805 \\
\hline \multicolumn{8}{|c|}{ High Rainfall and $60 \mathrm{~m}$ Depth } \\
\hline 1 & 0.4 & 2.5 & 2.1 & 31458 & 41826 & -10368 & -10368 \\
\hline 2 & 1.5 & 3.0 & 1.5 & 22470 & 41826 & -19356 & -29724 \\
\hline 3 & 1.75 & 5.0 & 3.25 & 48685 & 41826 & 6859 & -22865 \\
\hline 4 & 2.25 & 8.0 & 5.75 & 86135 & 41826 & 44309 & 21444 \\
\hline 5 & 2.75 & 12.5 & 9.75 & 146055 & 41826 & 104229 & 125673 \\
\hline
\end{tabular}




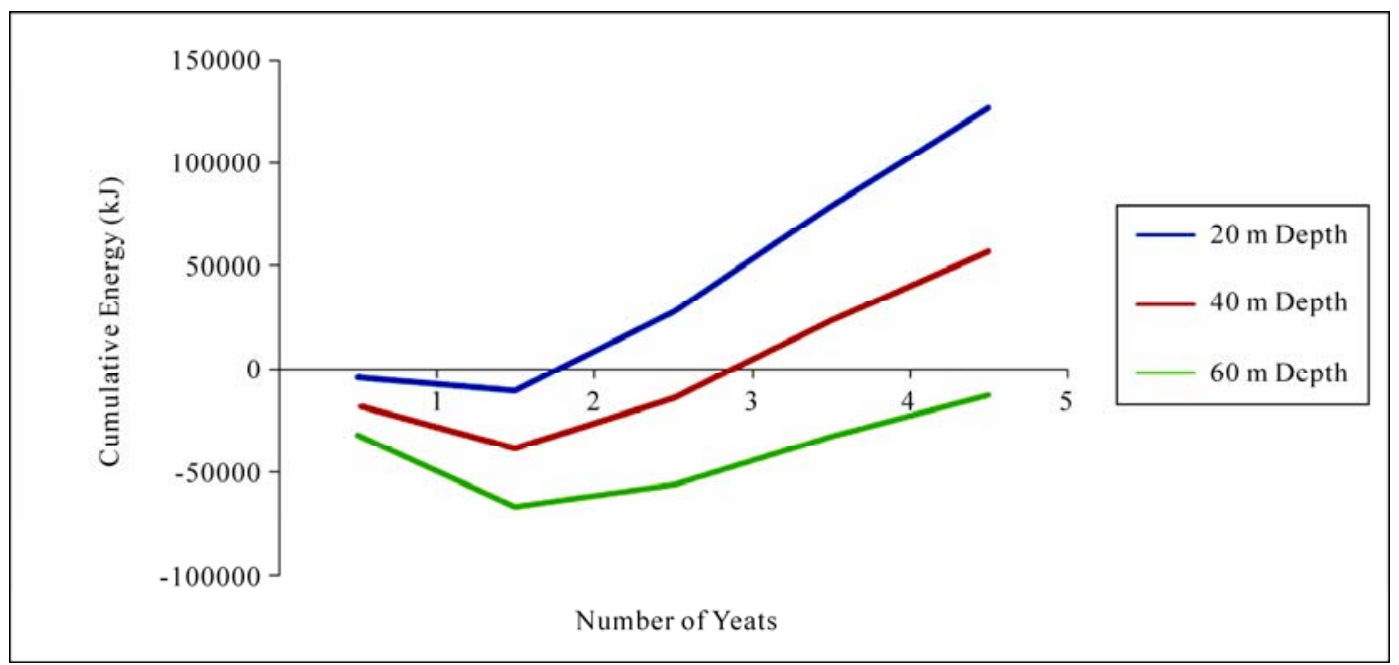

Figure 1. Cumulative energy vs. number of years (low rainfall).

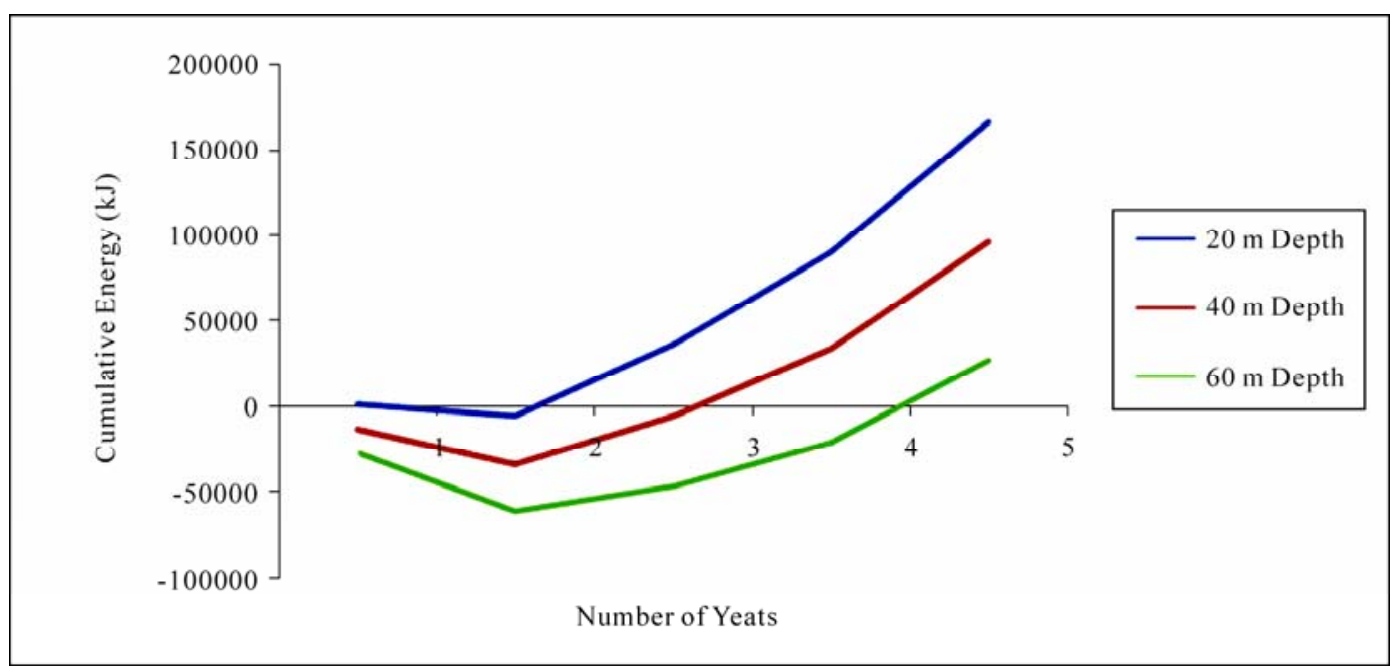

Figure 2. Cumulative energy vs. number of years (normal rainfall).

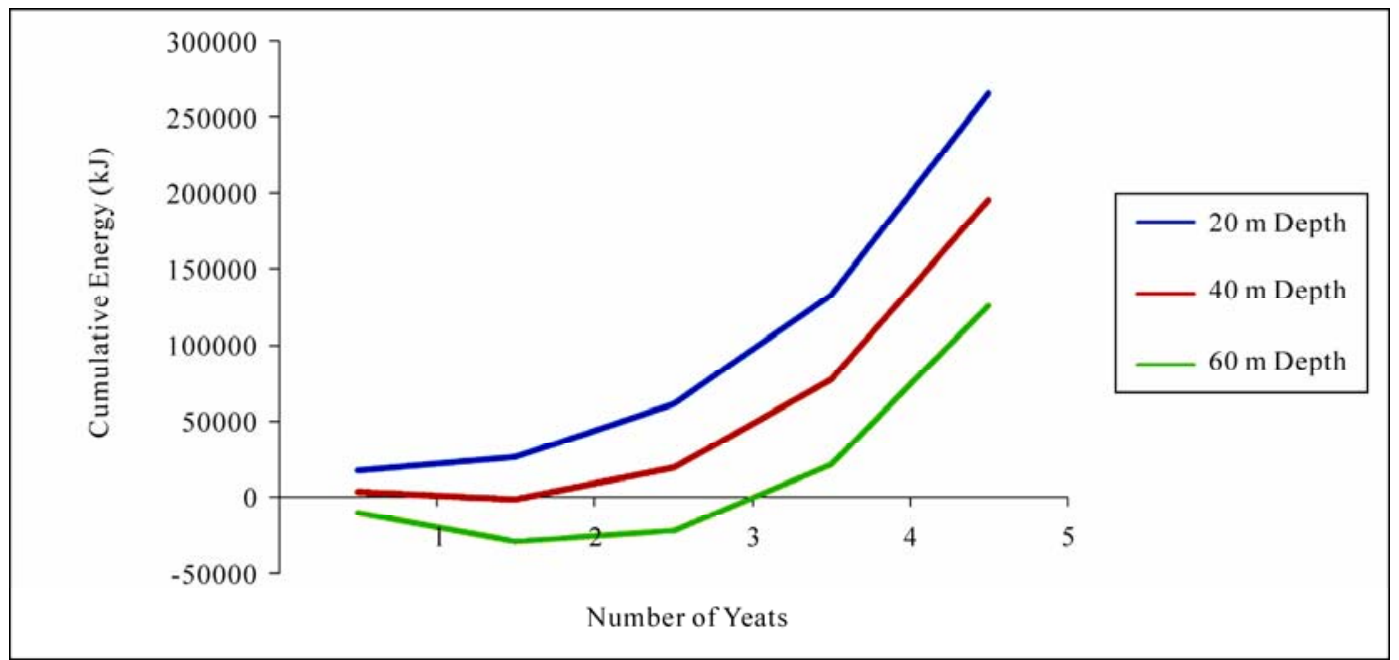

Figure 3. Cumulative energy vs. number of years (high rainfall). 


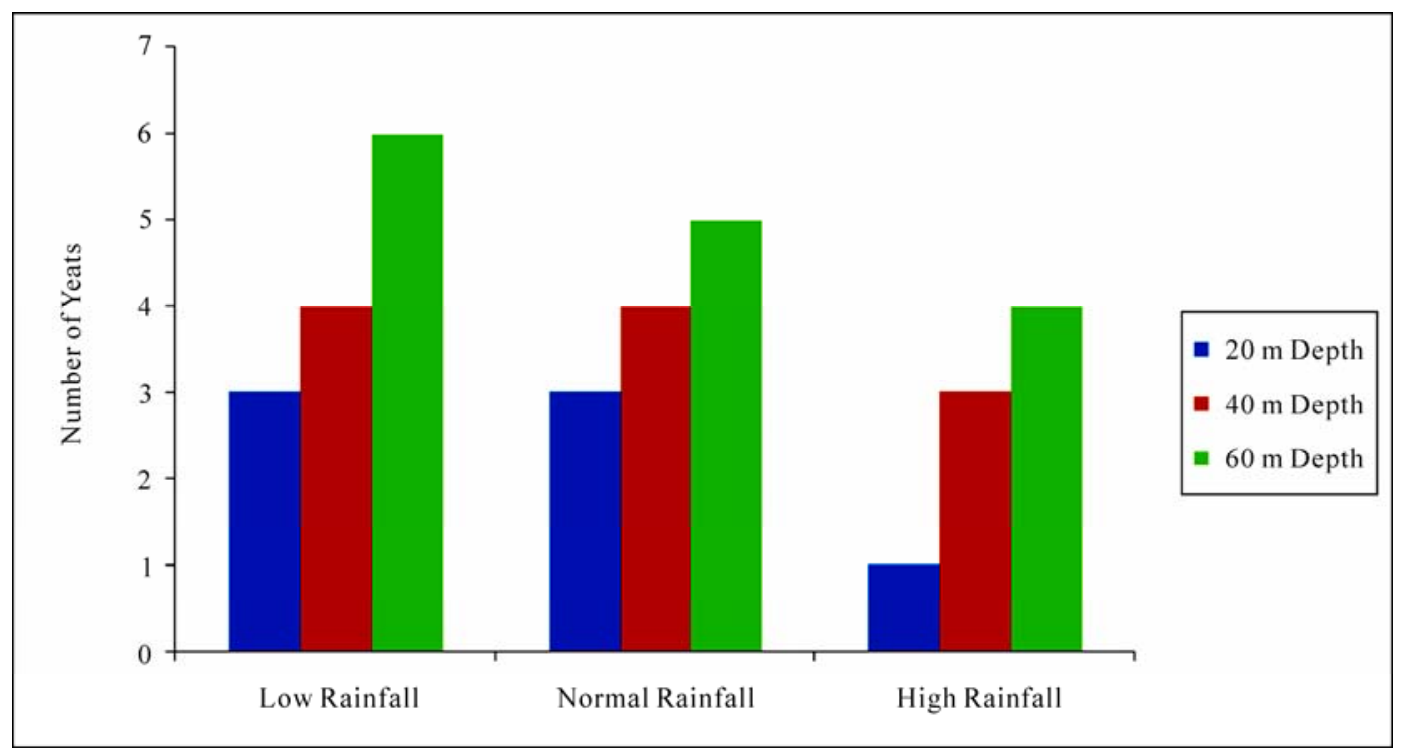

Figure 4. Energy yield stabilization.

\section{Energy Balance of Irrigated Jetropha Cultivation}

Due to variation of depth of water table and rainfall, cases for three different values of depth of water tables have been considered, $20 \mathrm{~m}, 40 \mathrm{~m}$ and $60 \mathrm{~m}$. Each of the three depths has been examined with different annual rainfall denoted as low, average and high rainfall conditions. Thus nine combinations were made for the analysis. Results of the year wise energy balance for these combinations are presented in Tables 4-6. The graphical representation of the energy balance is provided in Figures 1, 2 and 3.

\section{Energy Matrix}

When we correlate the data obtained from the 3 tables above, an "Energy Yield Stabilization" matrix can be created with Depth of the water table on the vertical axis and the Degree of rainfall on the horizontal axis. The number of years it takes to pay back the primary energy used for irrigation (termed as year of stabilization in this paper) can be indicated as shown in Table 7 below. The graphical representation of the matrix is provided in Figure 4.

If we consider the case of Jaipur, the average amount of rainfall is $500 \mathrm{~mm}$ per annum with the average depth of water table being $40 \mathrm{~m}$ [2]. From the above data, if anyone plans to invest in Jatropha plantation, he/she would start obtaining profits from the $4^{\text {th }}$ year onwards.

\section{Conclusions}

From the results shown in Tables 4-6, it can be concluded that areas having low rainfall and water table be
Table 7. Energy yield stabilization matrix.

\begin{tabular}{cccc}
\hline $\begin{array}{c}\text { Depth of Water } \\
\text { Table }(\mathbf{m})\end{array}$ & $\begin{array}{c}\text { Low } \\
\text { Rainfall }\end{array}$ & $\begin{array}{c}\text { Normal } \\
\text { Rainfall }\end{array}$ & $\begin{array}{c}\text { High } \\
\text { Rainfall }\end{array}$ \\
\hline $\mathbf{2 0}(\mathbf{m})$ & $3^{\text {rd }}$ year & $3^{\text {rd }}$ year & $1^{\text {st }}$ year \\
$\mathbf{4 0}(\mathbf{m})$ & $4^{\text {th }}$ year & $4^{\text {th }}$ year & $3^{\text {rd }}$ year \\
$\mathbf{6 0}(\mathbf{m})$ & - & $5^{\text {th }}$ year & $4^{\text {th }}$ year \\
\hline
\end{tabular}

low $60 \mathrm{~m}$, irrigated cultivation of bio-diesel will always have negative energy balance due to high energy requirement for pumping underground water. Whereas, in areas having normal rainfall and $60 \mathrm{~m}$ deep water table, the energy balance becomes positive only in the fifth year. In cases of high rainfall, irrigated cultivation of bio-diesel becomes energy positive in the fourth year. Low rainfall areas having high water table at $20 \mathrm{~m}$ depth, have neutral energy balance in the third year. Therefore, irrigated farming of Jetropha in low rainfall and deep water table areas should be discouraged. Further, if the energy requirement for oil extraction from seeds, transesterification of oil and other stages is accounted, even areas having normal rainfall and deep water table would also become unattractive for irrigated cultivation of biodiesel.

\section{REFERENCES}

[1] W. M. Achten, L. Verchot, Y. J. Franken, E. Mathijs, V. P. Singh R. Aerts, et al., "Jatropha Bio-Diesel Production and Use," Biomass and Bioenergy, Vol. 22, 2008.

[2] Ground Water Atlas of Rajasthan. Retrieved 20 November 2009. http://www.indianwaterportal.org

[3] E.U. Hydraulic Institute, "Pump Life Cycle Costs: A 
Guide to LCA Analysis for Pumping Systems," Executive Summary, Hydraulic Institute, Europump, Us Department of Energy's Office of Industrial Technologies (OIT), New Jersey, January 2001.

[4] Crop Cultivation, Retrieved 20 November 2009 from http://www.jatrophaworld.org

[5] A. Ludecke, "Cut Costs by Water Well Monitoring," World Pumps, April 2004, pp. 30-34.
[6] Energy Units, Retrieved 10 November 2009, from American Physical Society Sites:

http://www.aps.org/policy/reports/popa-reports/energy/un its.cfm

[7] Mukherjee, "Researching Jatropha Curcas," Horticulture Department, Agricultural Research Institute of India, Jaipur, 2008. 